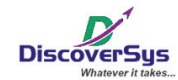

Published by DiscoverSys

\title{
Tantangan dalam akreditasi terbitan berkala ilmiah
}

\author{
Dewa Nyoman Wirawan ${ }^{1,2^{*}}$
}

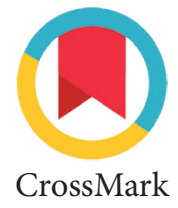

'Program Studi Magister IImu Kesehatan Masyarakat Universitas Udayana,

${ }^{2}$ Bagian IImu Kedokteran Komunitas dan IImu Kedokteran Pencegahan Fakultas Kedokteran Universitas Udayana

*Korespondensi penulis: Dewa Nyoman Wirawan, Program Studi Magister Ilmu Kesehatan Masyarakat Universitas Udayana, Bagian IImu Kedokteran Komunitas dan IImu Kedokteran Pencegahan Fakultas Kedokteran Universitas Udayana wirawandewa48@gmail.com
Merupakan suatu kehormatan bagi saya untuk menjadi Ketua Dewan Redaksi Public Health and Preventive Medicine Archive, dan merupakan kebahagiaan tidak terhingga bagi saya karena dengan persiapan yang melelahkan akhirnya penerbitan edisi perdana jurnal ini bisa diwujudkan.

Dalam pengantar ini saya ingin menyampaikan beberapa hal tentang rencana pengembangan jurnal ini ke depan dan juga ingin menyampaikan beberapa informasi yang mungkin ada manfaatnya bagi calon penulis. Dalam satu tahun terakhir saya dan para pengelola lainnya telah mendedikasikan banyak pikiran dan waktu untuk membidani kelahiran jurnal ini. Untuk itu saya mengucapkan terima kasih yang tulus kepada semua anggota dewan penyunting, penyunting pelaksana, tim validasi dan mitra bestari yang telah meluangkan waktunya dan memberikan dukungan tanpa lelah kepada kami.

Seperti halnya terbitan berkala ilmiah lain di Indonesia, tantangan berat yang akan dihadapi oleh jurnal pemula seperti Public Health and Preventive Medicine Archive adalah untuk mendapatkan tulisan-tulisan yang berkualitas di bidang public health dan preventive medicine serta untuk dapat mencapai semua persyaratan seperti diatur dalam Peraturan Direktur Jendral Pendidikan Tinggi Nomor 49/Dikti/Kep/2011 tentang Pedoman Akreditasi Terbitan Ilmiah yang terdiri atas 122 indikator yang menjadi penjati diri sebuah terbitan berkala ilmiah dan merupakan kriteria untuk menentukan peringkat dan status akreditasi suatu terbitan berkala ilmiah.

Jurnal ini akan diterbitkan dua kali dalam satu tahun dan agar dalam enam kali terbit atau dalam waktu tiga tahun bisa mengajukan akreditasi dan bisa memperoleh skor minimal 70, maka mulai sekarang harus dilakukan langkah-langkah yang memerlukan kerja keras guna mencapai target tersebut. Peraturan Direktur Jendral Pendidikan
Tinggi Nomor 49/Dikti/Kep/2011 memberikan bobot yang berbeda dalam penilaian terbitan berkala ilmiah yaitu penamaan terbitan berkala ilmiah (bobot 3), kelembagaan penerbit (bobot 5), penyuntingan (bobot 18), penampilan (bobot 8), gaya penulisan (bobot 13), substansi isi (bobot 40), keberkalaan (bobot 9), penyebarluasan (bobot 4) dan pengurangan nilai bila terjadi penyimpangan dengan bobot minus 20 .

Dengan adanya Peraturan Direktur Jendral Pendidikan Tinggi Nomor 49/Dikti/Kep/2011 tentang Pedoman Akreditasi Terbitan Ilmiah maka langkah-langkah dalam tiga tahun ke depan yang perlu ditempuh menjadi sangat jelas dan rinci baik bagi pengelola maupun calon penulis tetapi akan diperlukan kerja amat keras untuk mewujudkannya. Namun, dengan semangat yang tinggi, dedikasi dan kerja keras, baik dari pengelola maupun calon penulis, maka saya yakin akreditasi Public Health and Preventive Medicine Archive pada akhir tahun 2016 akan bisa diraih. Semoga kita semua mendapatkan berkah dari Tuhan Yang Maha Esa.

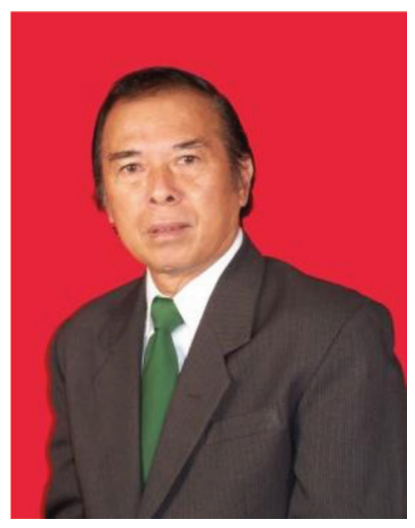

Dewa Nyoman Wirawan Ketua Dewan Redaksi 